\title{
Carbon turnover in peatland mesocosms exposed to different water table levels
}

\author{
CHRISTIAN BLODAU ${ }^{1,2, *}$, NATHAN BASILIKO ${ }^{1}$ and TIM R. MOORE ${ }^{1}$ \\ ${ }^{I}$ Department of Geography and Centre for Climate \& Global Change Research, McGill University, 805 \\ Sherbrooke Street West, Montreal, H3A 2K6, Canada; ${ }^{2}$ Current address: Limnological Research Sta- \\ tion, University of Bayreuth, Bayreuth, D-95444, Germany; *Author for correspondence (e-mail: \\ christian.blodau@uni-bayreuth.de; phone: 49921 552223; fax: 49921 552366)
}

Received 16 October 2001; accepted in revised form 21 January 2003

Key words: Carbon dioxide, DOC, Methane, Peatlands, Pore water

\begin{abstract}
Changes of water table position influence carbon cycling in peatlands, but effects on the sources and sinks of carbon are difficult to isolate and quantify in field investigations due to seasonal dynamics and covariance of variables. We thus investigated carbon fluxes and dissolved carbon production in peatland mesocosms from two acidic and oligotrophic peatlands under steady state conditions at two different water table positions. Exchange rates and $\mathrm{CO}_{2}, \mathrm{CH}_{4}$ and DOC production rates were simultaneously determined in the peat from diffusive-advective mass-balances of dissolved $\mathrm{CO}_{2}, \mathrm{CH}_{4}$ and DOC in the pore water. Incubation experiments were used to quantify potential $\mathrm{CO}_{2}, \mathrm{CH}_{4}$, and DOC production rates. The carbon turnover in the saturated peat was dominated by the production of DOC $\left(10-15 \mathrm{mmol} \mathrm{m} \mathrm{m}^{-2} \mathrm{~d}^{-1}\right)$ with lower rates of DIC $\left(6.1-8.5 \mathrm{mmol} \mathrm{m}^{-2} \mathrm{~d}^{-1}\right)$ and $\mathrm{CH}_{4}(2.2-4.2$ $\mathrm{mmol} \mathrm{m} \mathrm{m}^{-2} \mathrm{~d}^{-1}$ ) production. All production rates strongly decreased with depth indicating the importance of fresh plant tissue for dissolved $\mathrm{C}$ release. A lower water table decreased area based rates of photosynthesis (24-42\%), $\mathrm{CH}_{4}$ production (factor 2.5-3.5) and emission, increased rates of soil respiration and microbial biomass $\mathrm{C}$, and did not change DOC release. Due to the changes in process rates the $\mathrm{C}$ net balance of the mesocosms shifted by $36 \mathrm{mmol} \mathrm{m}^{-2} \mathrm{~d}^{-1}$. According to our estimates the change in $\mathrm{C}$ mineralization contributed most to this change. Anaerobic rates of $\mathrm{CO}_{2}$ production rates deeper in the peat increased significantly by a factor of 2-3.5 (DOC), 2.9-3.9 $\left(\mathrm{CO}_{2}\right)$, and 3-14 $\left(\mathrm{CH}_{4}\right)$ when the water table was lowered by $30 \mathrm{~cm}$. This phenomenon might have been caused by easing an inhibiting effect by the accumulation of $\mathrm{CO}_{2}$ and $\mathrm{CH}_{4}$ when the water table was at the moss surface.
\end{abstract}

\section{Introduction}

Peatlands cover about 450 million ha of land worldwide (Kivinen and Pakarinen 1981) and play an important role in the global biogeochemical cycles. They store large quantities of carbon (C), which is sequestered into organic matter through the synthesis of plant biomass. Peatlands have functioned as sinks for $\mathrm{C}$ since the end of the last glaciation because rates of plant production generally exceed rates of organic matter decomposition over millennia (Clymo 1984). Peatlands are also sources of methane $\left(\mathrm{CH}_{4}\right)$, contributing about $5 \%$ to the atmospheric $\mathrm{CH}_{4}$ burden (Fung et al. 1991), and sources of dissolved organic matter to surface waters (Urban et al. 1989). 
The important controls on organic matter decomposition and $\mathrm{C}$ mineralization are soil temperature, plant community structure, position of redox boundaries associated with the water table, and the chemical composition of plant tissues and peat (Whiting and Chanton 1993; Bubier et al. 1993; Bubier 1995; Yavitt et al. 1997). The effects of water table position on $C$ turnover in peat soils have been established by the determination of aerobic and anaerobic potential $\mathrm{CO}_{2}$ and $\mathrm{CH}_{4}$ production rates in flask experiments with disturbed peat samples (Yavitt et al. 1987, 1990, 1997; Öquist and Sundh 1998; Kettunen et al. 1999) and by measuring the exchange of $\mathrm{CO}_{2}$ and $\mathrm{CH}_{4}$ with the atmosphere in peat columns devoid of vegetation (Moore and Knowles 1989; Moore and Dalva 1993; Aerts and Ludwig 1997). These studies documented that lower water tables increase $C$ mineralization rates, and decrease $\mathrm{CH}_{4}$ emissions from peat soils. In mesocosm experiments it was also shown that Sphagnum mosses grow more slowly when the water table is lowered (Williams et al. 1999).

Process rates within the intact peat soils leading to these changes, however, have not been quantified yet. The simultaneous response of processes in the $\mathrm{C}$ cycle, such as photosynthetic $\mathrm{CO}_{2}$ uptake, mineralization of organic $\mathrm{C}$ and release of dissolved organic carbon (DOC), to different water tables, and their net effect on the $\mathrm{C}$ balance have not been investigated in studies that are based on controlled experiments with intact peatland mesocosms. This is, however, desirable because a difficulty in the interpretation of $\mathrm{CO}_{2}, \mathrm{CH}_{4}$ and DOC exchange data from field studies arises from the covariance of environmental controls and the interaction of production, storage and transport of dissolved C (Walter and Heimann 2000; Blodau and Moore 2002b).

In recognition of this situation our specific objectives were (I) to quantify the processes involved in the carbon cycle of intact peat soils and (II) to examine the short-term effect of water table levels on these processes, the carbon fluxes and the carbon balance. To these ends vegetated mesocosms were used, which left the soil structure intact and allowed for the simultaneous determination of export, production and storage of dissolved carbon and the exchange of $\mathrm{CO}_{2}$ and $\mathrm{CH}_{4}$ with the atmosphere. The mesocosms were kept under controlled conditions and exposed to different water table levels. The results of this study should provide useful baseline information about $\mathrm{CO}_{2}, \mathrm{CH}_{4}$, and DOC production and emission from acidic and oligotrophic peatlands.

\section{Methods}

Sites

We used peat cores from two peatlands in central and eastern Canada. The first site at Mer Bleue (MB), near Ottawa, eastern Ontario, Canada, is an open, slightly domed, acidic and oligotrophic peatland that is dominated by mosses (e.g., Sphagnum capillifolium, S. angustifolium, S. magellanicum and Polytrichum strictum) and 
shrubs (e.g., Ledum groenlandicum, Chamaedaphne calyculata, Kalmia angustifolia, Vaccinium myrtilloides). The second site in the Experimental Lakes Area (ELA), near Kenora, northwestern Ontario, Canada, is a small acidic and oligotrophic peatland located in the northwestern watershed of Lake 239 on the Precambrian Shield (Bayley et al. 1986). The peatland is dominated by black spruce ( $P i$ cea mariana) and mosses (S. magellanicum, S. angustifolium and S. fuscum).

\section{Definitions and conventions}

The term mesocosm is used for the experiments with intact peat soils. The term incubations is used for flask experiments with peat taken from the peat cores following mesocosm experiments. Rates in mesocosms, obtained from mass balances, are referred to as in situ, whereas rates in flask incubations are referred to as potential turnover rates. Carbon dioxide is used synonymously with dissolved inorganic carbon (DIC), because dissolved $\mathrm{CO}_{2}$ was, at $\mathrm{pH}$ values of below 3-5, the predominating carbonate species. The term water table refers to the depth at which water could be extracted by suction with a syringe. Losses of $\mathrm{CO}_{2}$ and $\mathrm{CH}_{4}$ from the peat to the atmosphere or due to drainage have been given a positive sign. All indicators of variability in the text and figures are standard deviations. The term soil respiration is used for the sum of decomposition and plant respiration. All production values are based on dry weight or volume of peat.

\section{Mesocosm experiments}

Peat cores, $20 \mathrm{~cm}$ in diameter and $75 \mathrm{~cm}$ long, were collected in PVC tubes from hollows in fall, and a drainage mesh and cap attached at the bottom. The vegetation, consisting primarily of Sphagnum mosses, minor numbers of Polytrichum and small specimens of Ledum groenlandicum, Chamaedaphne calyculata, and Kalmia angustifolia, was left intact. Pore water samplers (Bev-Line IV, Cole Parmer, $7 \mathrm{~mm}$ outer diameter, $3 \mathrm{~mm}$ inner diameter, ca. 30 perforations per sampler) were inserted horizontally at $2-\mathrm{cm}$ intervals. The water table was adjusted with distilled water to 2-6 $\mathrm{cm}$ below the moss cover and kept constant. The temperature was initially 22 ${ }^{\circ} \mathrm{C}$ during the day and $8{ }^{\circ} \mathrm{C}$ during the night. After day 50 the temperature was lowered to $12{ }^{\circ} \mathrm{C}$ (day) and $8{ }^{\circ} \mathrm{C}$ (night) to slow down the abundant Sphagnum growth and the $\mathrm{C}$ mineralization rates. Humidity was kept at $70 \% \mathrm{rH}$. Light intensity was adjusted to $250 \mu \mathrm{mol} \mathrm{m} \mathrm{m}^{-2} \mathrm{~s}^{-1}$. Solution was added with a sprinkler 5 to 6 days a week, and water manually retrieved at 2 to $3 \mathrm{~mm} \mathrm{~d}^{-1}$ from the base of the mesocosm. The inflowing solute contained $\mathrm{H}_{3} \mathrm{O}^{+}\left(92 / 358 \mu \mathrm{mol} \mathrm{L}^{-1}\right), \mathrm{SO}_{4}^{2-}(26 / 104$ $\left.\mu \mathrm{mol} \mathrm{L}{ }^{-1}\right), \mathrm{NO}_{3}^{-}\left(40 / 120 \mu \mathrm{mol} \mathrm{L}^{-1}\right), \mathrm{NH}_{4}^{+}\left(40 / 120 \mu \mathrm{mol} \mathrm{L}{ }^{-1}\right)$ at two concentration levels, and $\mathrm{Ca}^{2+}\left(30 \mu \mathrm{mol} \mathrm{L}{ }^{-1}\right), \mathrm{Mg}^{2+}\left(15 \mu \mathrm{mol} \mathrm{L}{ }^{-1}\right), \mathrm{Na}^{+}\left(50 \mu \mathrm{mol} \mathrm{L}{ }^{-1}\right)$ and $\mathrm{K}^{+}(5$ $\left.\mu \mathrm{mol} \mathrm{L}{ }^{-1}\right)$ and $\mathrm{Cl}^{-}\left(150-265 \mu \mathrm{mol} \mathrm{L^{-1 }}\right)$. These concentration levels were due to the mesocosms being part of a $\mathrm{N}$ and $\mathrm{S}$ deposition study. The analyses showed that the concentrations of DIC, dissolved $\mathrm{CH}_{4}$ and DOC and the $\mathrm{CO}_{2}$ and $\mathrm{CH}_{4}$ fluxes from the mesocosms were unaffected by the different treatments (Blodau 2001). Thus the $\mathrm{N}$ and $\mathrm{S}$ treatments are not discussed. 
Measurements started after an initial equilibration period of 60 days, and were subsequently carried out for about 220 days on an approximately monthly basis. About 60 days after beginning of the experiment the water table level was lowered to ca. $36 \mathrm{~cm}$ below the surface in 8 mesocosms by drainage through a pore water sampler. The lower water tables lead to decreased evaporation rates so that water tables temporarily increased again in this treatment. We resorted to a permanent drainage at $36 \mathrm{~cm}$. Between day 143 and 223 the water table level in the mesocosms was between 0 and $2 \mathrm{~cm}$ and 30 and $33 \mathrm{~cm}$, respectively, below the original moss surface.

The total moss biomass in the mesocosms was between 200 and $600 \mathrm{~g} \mathrm{~m}^{-2}$ (dry weight). This value is an upper estimate, since the Sphagnum were pulled from the mesocosms and all lower parts of living Sphagnum stems were included in the measurement. Carbon dioxide and $\mathrm{CH}_{4}$ exchange rates between the top of the mesocosms and the atmosphere were calculated from linear regressions of 4 to 6 measurements of gas concentrations in the chamber headspace at 8-minute intervals. Rates of photosynthesis were determined from the difference in $\mathrm{CO}_{2}$ exchange between opaque and transparent chambers. Due to the opaque sides of the transparent chamber the light levels were somewhat attenuated, so that the rates of photosynthesis represented minimum estimates. Regressions with $\mathrm{R}^{2}<0.75$ and obvious artifacts (e.g., exponential concentration increase) were eliminated even when $\mathrm{R}^{2}>$ 0.75. Moss growth was determined at intervals of ca. 3 months with the cranked wire technique (Clymo 1970) with 5-7 wires per core.

Differences between treatments were statistically analyzed with t-tests using the software package SPSS, release 5.0 after examination of the data distribution with normality plots.

\section{Incubation experiments}

Incubations with peat were carried out after the end of the mesocosm experiments at room temperature $\left(20^{\circ}-22{ }^{\circ} \mathrm{C}\right)$. Anaerobic potential production rates of $\mathrm{CO}_{2}$, $\mathrm{CH}_{4}$, and DOC were determined in four depth increments (8-12, 22-26, 32-36 and $58-62 \mathrm{~cm})$. Peat cores were extruded, dissected and sampled under $\mathrm{N}_{2}$ in a glove chamber. The peat (50-100 g wet weight, $7.2 \pm 3.2 \mathrm{~g}$ (s.d.) dry weight) was placed in $125-250 \mathrm{~mL}$, rubber-stoppered Erlenmeyer flasks and fully immersed in deaerated water. No gas headspace was left in the flask except from a small bubble. The flasks were not shaken, but occasionally turned over to avoid a chemical stratification within the flasks. The water was sampled through suction samplers inserted through the rubber stoppers. Over 7 to 9 days, $10 \mathrm{~mL}$ of water were extracted on 5 to 6 occasions and $\mathrm{CO}_{2}, \mathrm{CH}_{4}$, and DOC determined as described below. The extracted water was replaced with the deaerated solutions. Rates were determined by linear regressions of concentration over time corrected for the replacement of water sampled from the flasks with the deaerated solution.

Potential $\mathrm{CO}_{2}$ production under aerobic conditions was determined for peat removed from 8 depths in 6 to $12 \mathrm{~cm}$ increments in each core following the in situ experiments. Approximately $5 \mathrm{~g}$ of peat (wet weight) from each depth was placed 
into a $50 \mathrm{ml}$ Erlenmeyer flask. Twenty milliliters of deionized water was added to create a slurry that helped to eliminate any local regions of anoxia in the peat. Flasks were sealed with rubber stoppers and shaken on a rotary shaker at 200 RPM for 3 days. Gas from the headspace was sampled daily and analyzed to determine $\mathrm{CO}_{2}$ concentrations. Rates were determined as the volume corrected linear regression of concentration over time.

\section{Determination of extractable microbial carbon}

Extractable microbial $\mathrm{C}$ was determined in peat taken from the same locations used for aerobic $\mathrm{CO}_{2}$ production potential measurements. Fumigation with $\mathrm{CHCl}_{3}$ and extraction with $0.5 \mathrm{M} \mathrm{K}_{2} \mathrm{SO}_{4}$ was carried out with slight modifications according to Voroney et al. (1993). Approximately $40 \mathrm{~g}$ of peat (wet weight) from each bulk sample were split into two $20 \mathrm{~g}$ samples. One sample was placed in a vacuum dessicator and fumigated with ethanol-free $\mathrm{CHCl}_{3}$ in absence of light for 24 hours. Chloroform vapor and residue was then removed through repeated evacuation. All samples were sealed in plastic containers containing $\mathrm{K}_{2} \mathrm{SO}_{4}$ solution, shaken for 1 $\mathrm{hr}$ at $200 \mathrm{RPM}$ on an oscillating shaker, and filtered with $0.45 \mu \mathrm{m}$ glass fiber filters. Dissolved organic carbon (DOC) was measured with a TOC analyzer after $\mathrm{pH}$ adjustment to 2.5 and sparging with $\mathrm{CO}_{2}$-free $\mathrm{N}_{2}$ for $10 \mathrm{~min}$. Extractable DOC was measured directly in extracts from the non-fumigated samples. Microbial biomass $\mathrm{C}$ was calculated by subtracting the non-fumigated extractable DOC from the fumigation-extractable DOC. No extraction efficiency coefficients were used in our calculations as we were interested in differences among samples, and because there have been reports of a large range of $C$ extraction efficiency coefficients $\left(\mathrm{K}_{\mathrm{EC}}, \mathrm{K}_{\mathrm{EN}}\right)$ (Sparling et al. 1990; Brookes et al. 1985) for different soils.

\section{Pore water and air analyses}

About once a month 5-10 $\mathrm{ml}$ of pore water or air was extracted from the suction samplers from zero to 12 centimeter below the water table in 2-cm and below in $6-\mathrm{cm}$ or $12-\mathrm{cm}$ increments with stoppered syringes. DOC was determined after filtration of extracted pore water with a syringe micro-filter $(0.45 \mu \mathrm{m}$, nylon) on a Shimadzu 5050 TOC analyzer. Dissolved inorganic carbon (DIC), and $\mathrm{CH}_{4}$ were determined on a Shimadzu Mini 2 gas chromatograph with methanizer $\left(\mathrm{CO}_{2}\right)$ in the gas phase of $1.8 \mathrm{~mL}$ vials after addition of $20 \mu \mathrm{L}$ of $4 \mathrm{M} \mathrm{HCl}$ and $0.5 \mathrm{~mL}$ sample. Losses of $\mathrm{CO}_{2}$ and $\mathrm{CH}_{4}$ from the $\mathrm{GC}$ vials were corrected with exponential loss functions $\left(\mathrm{n}=16, \mathrm{R}^{2}=0.99\right.$; concentration of $\mathrm{CO}_{2}: \mathrm{C}=\mathrm{C}_{0} 10^{(-0.0264 \mathrm{t})}$ and concentration of $\mathrm{CH}_{4}: \mathrm{C}=\mathrm{C}_{0} 10^{(-0.00635}$ t) with t: (h). The original dissolved concentration was reconstructed using the head space concentrations, the volumes of headspace and water phase and Henry's law $\left(\mathrm{K}_{\mathrm{H}}=10^{-1.5}\left(\mathrm{~mol} \mathrm{~L}^{-1} \mathrm{~atm}^{-1}\right)\right.$ for $\mathrm{CO}_{2}$ and $\mathrm{K}_{\mathrm{H}}=2 \times 10^{-3}\left(\mathrm{~mol} \mathrm{~L}^{-1} \mathrm{~atm}^{-1}\right)$ for $\mathrm{CH}_{4}$. In the unsaturated zone of the mesocosms $\mathrm{CO}_{2}$ and $\mathrm{CH}_{4}$ were directly determined on gas samples that were extracted from the sampling ports with syringes. $\mathrm{O}_{2}$ was determined amperometrically with a low-current electrode and $\mathrm{pH}$ potentiometrically on 0.5 to $3 \mathrm{~mL}$ of 
sample with a conventional meter (Orion). $\mathrm{O}_{2}$ contamination due to the sampling procedure was ca. $0.5 \mathrm{mg} \mathrm{L}^{-1}$. In a few mesocosms concentrations of formate, acetate, propionate, butyrate were determined by HPLC, at the end of the experiment, but in all samples the concentrations were below the detection limit of ca. 50 $\mu \mathrm{mol} \mathrm{L}{ }^{-1}$.

\section{Calculation of in situ production rates}

The water movement in the peat cores was sufficiently described by advective-diffusive transport (Blodau and Moore 2002a). Variability in concentration profiles through the use of suction samplers was minimized by averaging concentration data within $6 \mathrm{~cm}$ or $12 \mathrm{~cm}$ depth segments. For these segments, vertical advective-diffusive mass balances were calculated, using temperature-corrected diffusion coefficients for dissolved $\mathrm{CO}_{2}, \mathrm{CH}_{4}$ and $\mathrm{O}_{2}$ (Lerman 1979). Net turnover is then given by Equation (1):

$$
R=\Delta S_{A} / \Delta T-\left(D_{\text {in }} \Delta C_{A} / \Delta X\right)_{i n}+\left(D_{\text {out }} \Delta C_{A} / \Delta X\right)_{\text {out }}-v\left(C_{A, \text { in }} C_{A, \text { out }}\right)
$$

in which

$\mathrm{R}=$ turnover rate $\left(\mathrm{nmol} \mathrm{cm} \mathrm{cm}^{-3} \mathrm{~d}^{-1}\right)$,

$\mathrm{C}_{\mathrm{A}}=$ concentration of component $\mathrm{A}$,

$\Delta \mathrm{S}_{\mathrm{A}} / \Delta \mathrm{T}=$ change in storage of component $\mathrm{A}$ in a segment $\left(\mathrm{nmol} \mathrm{cm} \mathrm{cm}^{-3} \mathrm{~d}^{-1}\right)$,

$\mathrm{D}=$ whole peat diffusion coefficient $\left(\mathrm{cm}^{2} \mathrm{~d}^{-1}\right)$,

$\Delta \mathrm{C}_{\mathrm{A}} / \Delta \mathrm{x}=$ concentration gradient of component $\mathrm{A}\left(\mathrm{nmol} \mathrm{cm}{ }^{-4}\right)$,

$\mathrm{v}=$ advection rate $\left(\mathrm{cm} \mathrm{d}^{-1}\right)$ The effect of bulk density on diffusion coefficients was taken into account by using separately determined bulk density profiles, which were fitted against a power function $(\mathrm{Bd}=0.0107 \times 0.567$ with $\mathrm{Bd}=$ bulk density $\left(\mathrm{g} \mathrm{cm}^{-3}\right)$; $\mathrm{x}$ : depth $(\mathrm{cm}) ; \mathrm{R}^{2}=0.79$; Blodau and Moore (2002a)). Based on preliminary calculations with tabulated diffusion coefficients (Cornel et al. 1985), diffusion was neglected for the calculation of DOC turnover. The concentration profiles were treated as a series of steady states and rates calculated from advective-diffusive mass balances. Diffusive exchange with the atmosphere was calculated using Fick's 1st law. For this calculation, it was assumed that gaseous concentrations 1-2 $\mathrm{cm}$ above the water table were in equilibrium with the dissolved concentration at the water table.

To obtain turnover rates under unsaturated conditions, we separately determined water content and bulk density of the depth segments under identical conditions and fitted the data to linear (water content, $\mathrm{R}^{2}=0.97$ ) and square functions (bulk density, $\mathrm{R}^{2}=0.79$ ). Equation (2) (Jin and Jury 1996; Millington and Quirk 1961), and gaseous, temperature-corrected diffusion coefficients (Lerman 1979) were used to estimate unsaturated diffusion coefficients in the peat:

$$
\alpha(a)=a^{2} \beta^{-2 / 3}
$$

in which 
$\alpha=$ diffusion coefficient correction factor (),

$\mathrm{a}=$ volumetric air content ()

$\beta=$ soil porosity ()

Ambient atmospheric concentrations and diffusive mass balances were used to calculate turnover and diffusive exchange rates of $\mathrm{CO}_{2}$ and $\mathrm{CH}_{4}$ with the atmosphere.

\section{Results}

Pore water concentrations

$1-3 \mathrm{~cm}$ below the water table, the pore waters became anoxic (Figure 1A). The $\mathrm{pH}$ values in the pore water ranged from 3.9 to 4.2 both at high and low water table levels. DOC was the predominant form of $\mathrm{C}$ in the pore water with concentrations increasing with depth from about 2.5 to $7.5 \mathrm{mmol} \mathrm{L}^{-1}$ (Figure 1B). DIC concentrations increased from $0.1-0.6 \mathrm{mmol} \mathrm{L}^{-1}$ at the water table to $2-5 \mathrm{mmol} \mathrm{L}^{-1}$ at larger depths and were on average fairly similar in ELA and MB mesocosms (Figure 1C).

Lowering of the water table resulted in degassing of $\mathrm{CO}_{2}$ from the unsaturated zone and volumetric concentrations of $190-10000$ ppmv $\left(8-440 \mu \mathrm{mol} \mathrm{L}^{-1}\right)$ at and above the water table. In these mesocosms, the DIC gradient was very steep so that outflow concentrations were nearly identical in the treatments (Figure 1C). In the unsaturated zone, $\mathrm{CO}_{2}$ concentrations were generally smallest below the Sphagnum moss surface ( $402 \pm 140 \mathrm{ppmv}$, with air background of ca. 504 ppmv), indicating uptake from the atmosphere and the soil. Methane concentrations generally ranged from $10-190 \mu \mathrm{mol} \mathrm{L}^{-1}$ just below the water table to $500-1000 \mu \mathrm{mol} \mathrm{L}{ }^{-1}$ at depths of 40 to $70 \mathrm{~cm}$ (Figure 1D). In the unsaturated zone concentrations were generally between 2 and $30 \mathrm{ppmv}\left(0.1-1.3 \mu \mathrm{mol} \mathrm{L}^{-1}\right)$ and increased towards the water table to $13-100 \mathrm{ppmv}$.

\section{Carbon fluxes and in situ production rates}

The Sphagnum grew on average between $2 \mathrm{~mm}$ and $20 \mathrm{~mm} \mathrm{month}^{-1}$, being faster at the beginning of the experiments and in the ELA cores, and when the water table was kept high (Figures 2A and B). Carbon dioxide uptake by photosynthesis was higher in Mer Bleue mesocosms than in ELA mesocosms and decreased when the water table level was lowered (Table 1, Figures 2C and D) by an average of $24 \%$ (MB) and $42 \%$ (ELA). Soil respiration fluxes were greater in the ELA than the MB mesocosms, and increased with lowered water table levels (Figures 2E \& F). Methane emissions were significantly larger from ELA than MB mesocosms, at both high and low water table levels and strongly decreased after lowering the water table (Figures $2 \mathrm{G} \mathrm{\&} \mathrm{H)}$. In the mesocosms with a high water table level, the average in situ DIC production was about $7.3 \mathrm{mmol} \mathrm{m} \mathrm{m}^{-1}$ of which ca. $1.6 \mathrm{mmol} \mathrm{m}^{-2} \mathrm{~d}^{-1}$ 


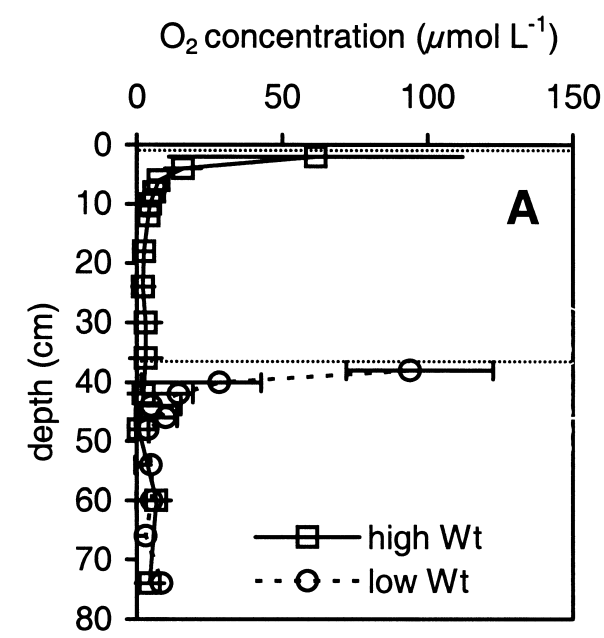

DOC concentration $\left(\mu \mathrm{mol} \mathrm{L}{ }^{-1}\right)$ )
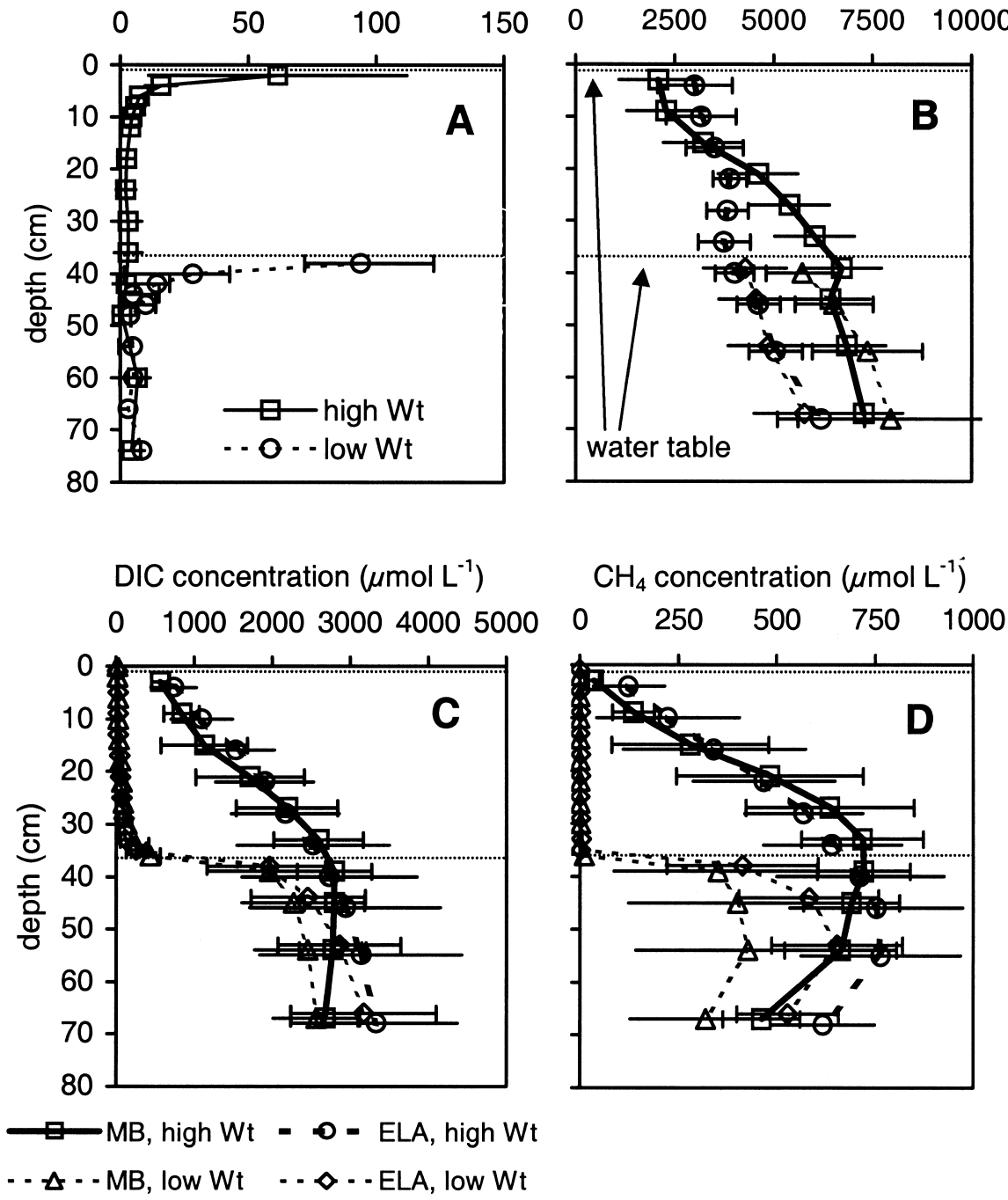

$\mathrm{CH}_{4}$ concentration $\left(\mu \mathrm{mol} \mathrm{L} \mathrm{L}^{-1}\right)$
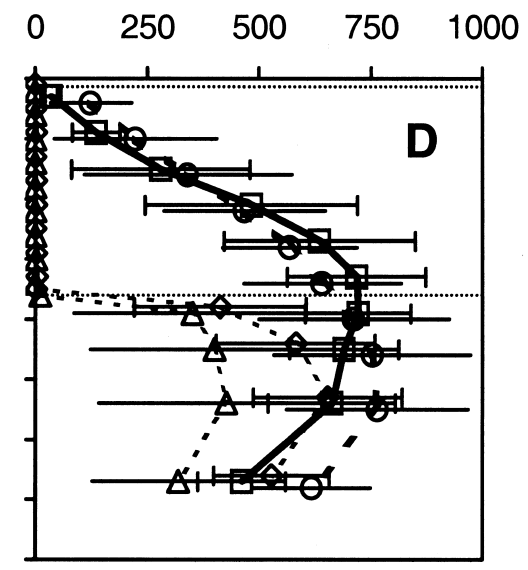

Figure 1. Average concentrations of dissolved $\mathrm{O}_{2}$, DOC, DIC and $\mathrm{CO}_{2}$, and $\mathrm{CH}_{4}$ during the experiment. Bars indicate the average standard deviations of concentrations in mesocosms at individual sampling dates. Note the strong concentration increase in DIC and $\mathrm{CH}_{4}$ concentrations at $35-45 \mathrm{~cm}$ depth in the low water table treatments.

was due to oxic respiration. Most of the DIC produced left the mesocosms with the outflow (average 68-72\%) and the remainder by diffusion across the water table (Table 1). The calculated fluxes and the production rates were nearly identical (Table 1). 
begin of water table and temperature change from $22 / 8$ to $12 / 8 \mathrm{C}$
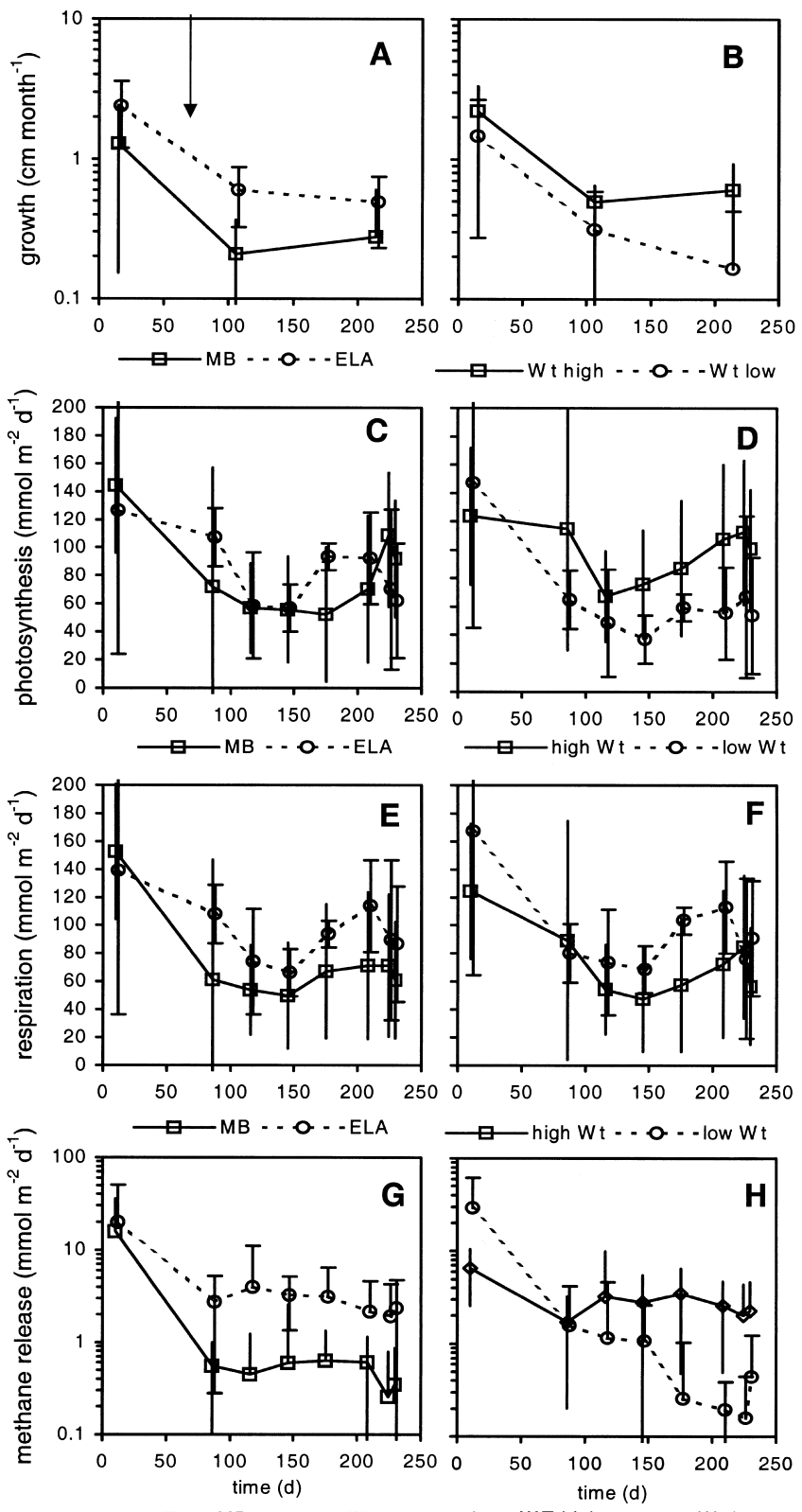

Figure 2. Moss growth, rates of photosynthesis at "daylight", soil respiration and $\mathrm{CH}_{4}$ emission during the experiment. Bars indicate standard deviations. The water table levels was varied after the first measurement. The figures show that that the impact of the water table change was largest on the $\mathrm{CH}_{4}$ emission and smallest on the respiration. 
Table 1. Depth-aggregated net in situ $\mathrm{CO}_{2}, \mathrm{CH}_{4}$ and DOC production rates and fluxes, as calculated from pore water profiles and chamber measurements $\left(\mathrm{mmol} \mathrm{m}^{-2} \mathrm{~d}^{-1}\right)$. Means and standard deviations are presented. Dissolved fluxes represent the outflow from the mesocosm, and diffusive fluxes the estimated diffusive flux across the water table.

\begin{tabular}{|c|c|c|c|c|c|c|}
\hline \multirow{2}{*}{$\begin{array}{l}\text { Site } \\
\text { Species }\end{array}$} & \multicolumn{3}{|l|}{ MB } & \multicolumn{3}{|l|}{ ELA } \\
\hline & $\mathrm{CO}_{2}$ & $\mathrm{CH}_{4}$ & DOC & $\mathrm{CO}_{2}$ & $\mathrm{CH}_{4}$ & DOC \\
\hline \multicolumn{7}{|c|}{ High water table ${ }^{\S}$} \\
\hline Net production & $6.1 \pm 0.8$ & $1.1 \pm 0.7$ & $15.4 \pm 3.9$ & $8.5 \pm 1.6$ & $1.5 \pm 0.5$ & $9.7 \pm 2.3$ \\
\hline Flux, dissolved ${ }^{\mathrm{a}}$ & $4.4 \pm 0.6$ & $0.88 \pm 0.12$ & $13.3 \pm 0.9$ & $5.8 \pm 2.0$ & $1.2 \pm 0.2$ & $10.1 \pm 1.8$ \\
\hline Flux, diffusive ${ }^{b}$ & $2.1 \pm 0.8$ & $0.08 \pm 0.05$ & - & $2.3 \pm 1.2$ & $0.37 \pm 0.30$ & - \\
\hline $\begin{array}{l}\text { Flux, chamber } \\
\text { photosynthesis }^{\mathrm{d}}\end{array}$ & $\begin{array}{l}47 \pm 8 \\
41 \pm 9\end{array}$ & $0.94 \pm 0.30$ & - & $\begin{array}{l}85 \pm 15 \\
54 \pm 16\end{array}$ & $3.2 \pm 2.3$ & - \\
\hline \multicolumn{7}{|l|}{ Low water table ${ }^{\S}$} \\
\hline $\begin{array}{l}\text { Net production } \\
\text { median }\end{array}$ & $\begin{array}{l}170 \pm 460 \\
152\end{array}$ & n. q. ${ }^{\mathrm{e}}$ & n. q. ${ }^{\mathrm{e}}$ & $\begin{array}{l}139 \pm 239 \\
117\end{array}$ & n. q. ${ }^{\mathrm{e}}$ & n. q. ${ }^{\mathrm{e}}$ \\
\hline Flux, dissolved & $4.2 \pm 0.9$ & $0.58 \pm 0.37$ & $14.1 \pm 3.9$ & $5.1 \pm 2.7$ & $1.02 \pm 0.23$ & $9.4 \pm 1.9$ \\
\hline $\begin{array}{l}\text { Flux, chamber } \\
\text { photosynthesis }\end{array}$ & $\begin{array}{l}77 \pm 15 \\
31 \pm 15\end{array}$ & $0.01 \pm 0.25$ & - & $\begin{array}{l}95 \pm 10.2 \\
23 \pm 12\end{array}$ & $0.88 \pm 1.15$ & - \\
\hline
\end{tabular}

$\S$ at $8 / 12{ }^{\circ} \mathrm{C}$; a advective removal from the mesocosmsms; ${ }^{b}$ diffusive export to the water table; ${ }^{\mathrm{c}}$ measured flux from the moss surface; difference between chamber fluxes under shrouded and non-shrouded conditions; ${ }^{\text {en.q. }}=$ not quantified due to unknown contribution of the unsaturated zone

In situ DIC production rates strongly decreased with depth (Figure 3C). The in situ $\mathrm{CO}_{2}$ production rates in the unsaturated zone (Equation 2) were, on average, between 1200 and $12000 \mathrm{nmol} \mathrm{g}^{-1} \mathrm{~d}^{-1}$, and peaked at a depth of $18 \mathrm{~cm}$. The resulting, very poorly constrained, estimate of net production for these mesocosms was $139 \pm 239 \mathrm{mmol} \mathrm{m}^{-2} \mathrm{~d}^{-1}$ (ELA) and $170 \pm 460 \mathrm{mmol} \mathrm{m}^{-2} \mathrm{~d}^{-1}$ (MB) (Table 1). In situ $\mathrm{CH}_{4}$ production rates decreased from an average of $200 \pm 36 \mathrm{nmol} \mathrm{g}^{-1} \mathrm{~d}^{-1}$ at $0-6 \mathrm{~cm}$ to a net consumption of $8 \pm 2 \mathrm{nmol} \mathrm{g} \mathrm{g}^{-1} \mathrm{~d}^{-1}$ at a depth of 60 to $74 \mathrm{~cm}$. The calculated diffusive flux across the water table (Table 1) was much smaller (0.08-0.37 mmol m $\left.\mathrm{m}^{-2} \mathrm{~d}^{-1}\right)$ than the measured $\mathrm{CH}_{4}$ emission rate (0.94-3.2 mmol $\left.\mathrm{m}^{-2} \mathrm{~d}^{-1}\right)$. This implies that the release of bubbles was the primary mechanism of $\mathrm{CH}_{4}$ emissions, and that the diffusive-advective mass balances probably accounted only for ca. 35-50\% of the total $\mathrm{CH}_{4}$ production rate. The in situ $\mathrm{CH}_{4}$ production rates in the unsaturated zone (Equation 2) indicated a $\mathrm{CH}_{4}$ sink of -174 $\pm 211 \mathrm{nmol} \mathrm{g}^{-1} \mathrm{~d}^{-1}$ between the water table and a depth of $32 \mathrm{~cm}$. Average in situ DOC production rates were $15.4 \pm 3.9 \mathrm{mmol} \mathrm{m}^{-2} \mathrm{~d}^{-1}(\mathrm{MB})$ and $9.7 \pm 2.3$ mmol m $\mathrm{m}^{-2} \mathrm{~d}^{-1}$ (ELA, Table 1). Rates decreased with depth from $2220 \pm 670$ $\mathrm{nmol} \mathrm{g} \mathrm{g}^{-1}(\mathrm{MB})$ and $2960 \pm 810 \mathrm{nmol} \mathrm{g} \mathrm{d}^{-1} \mathrm{~d}^{-1}$ (ELA) to $3 \pm 31 \mathrm{nmol} \mathrm{g}^{-1} \mathrm{~d}^{-1}$ and $21 \pm 9 \mathrm{nmol} \mathrm{g}^{-1} \mathrm{~d}^{-1}$ (Figure $4 \mathrm{~A}$ ).

With lower water table levels, average production rates increased at depths below the new water table, DIC by a factor 2.9 to 3.9 (t-test, $* \mathrm{P}<0.05, \mathrm{n}=8$; Figure $3 \mathrm{C}), \mathrm{CH}_{4}$ by a factor 3 to 14 (t-test, ${ }^{*} \mathrm{P}<0.05, \mathrm{n}=8$; Figure $5 \mathrm{~B}$ ) and DOC by a 


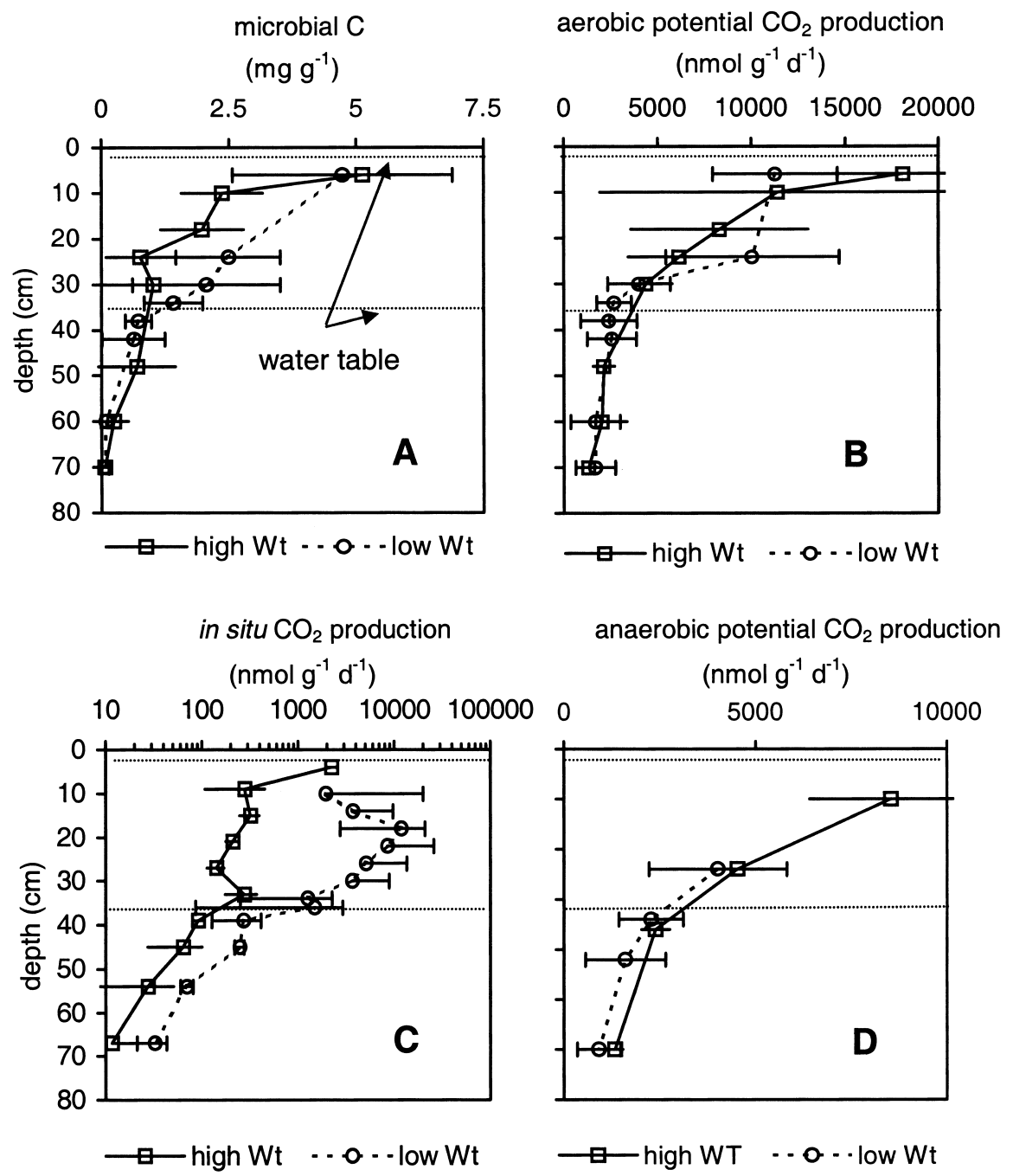

Figure 3. Average microbial C (A), aerobic potential production rates (B), in situ $\mathrm{CO}_{2}$ and DIC production rates $(\mathrm{C})$, and anaerobic potential $\mathrm{CO}_{2}$ production rates $(\mathrm{D})$. The figure illustrates the influence of depth and water table level on the $\mathrm{C}$ mineralization rates and microbial $\mathrm{C}$ concentrations.

factor 2 to 3.5 when compared to the high water table treatment (t-test, $* \mathrm{P}=0.05$, $\mathrm{n}=8$; Figure 4).

\section{Potential production rates}

The aerobic potential $\mathrm{CO}_{2}$ production rates followed the same depth trend as the in situ rates (Figure 3B) but were, on average, between $8(0-6 \mathrm{~cm})$ and 112 times $(70$ $\mathrm{cm})$ larger. The anaerobic potential DIC production rates also decreased with depth 

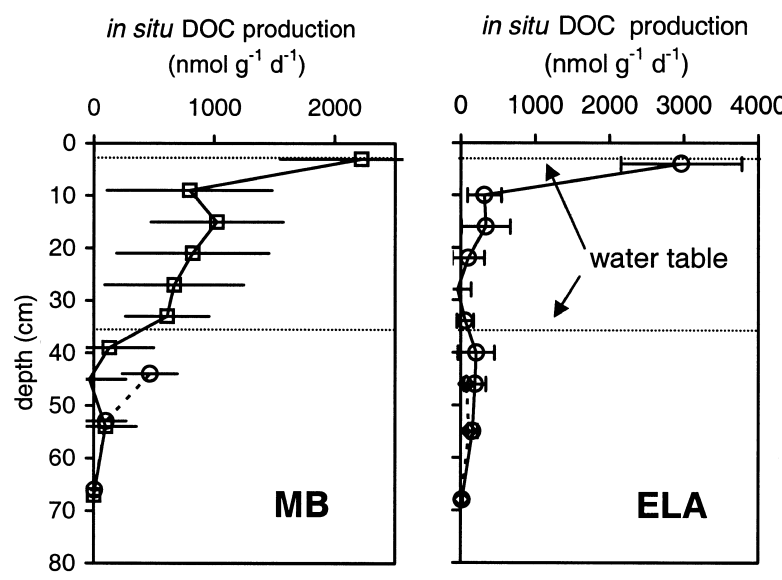

potential DOC production $\left(\mathrm{nmol} \mathrm{g} \mathrm{d}^{-1}\right)$

$1000020000 \quad 30000$

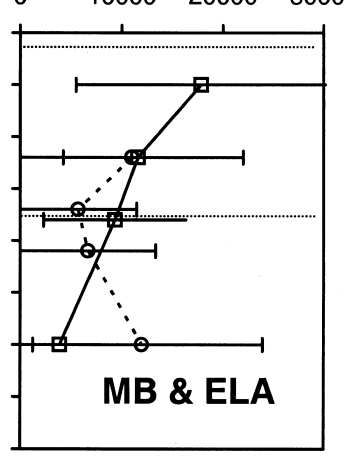

巴-high WT

- o . . low Wt

Figure 4. Average in situ (A) and potential (B) DOC production rates.

potential $\mathrm{CH}_{4}$ production $\left(\mathrm{nmol} \mathrm{g} \mathrm{g}^{-1} \mathrm{~d}^{-1}\right)$

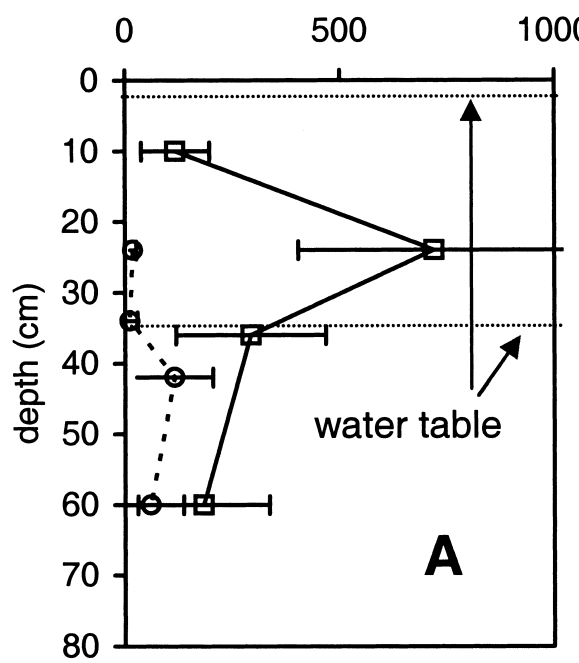

in situ $\mathrm{CH}_{4}$ production

$$
\left(\mathrm{nmol} \mathrm{g}{ }^{-1} \mathrm{~d}^{-1}\right. \text { ) }
$$

0 250

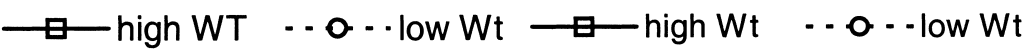

Figure 5. Potential (A) and average in situ $(\mathrm{B}) \mathrm{CH}_{4}$ production rates. Note the effect of a lowered water table on the $\mathrm{CH}_{4}$ production rates at $35-45 \mathrm{~cm}$ depth.

(Figure 3D) and were on average 1.4 times smaller than the potential aerobic rates. The potential $\mathrm{CH}_{4}$ production rates peaked on average at $24 \mathrm{~cm}$ and at $750 \pm 320$ nmol g ${ }^{-1} \mathrm{~d}^{-1}$ (Figure 5A). Decreasing the water table significantly reduced this rate 


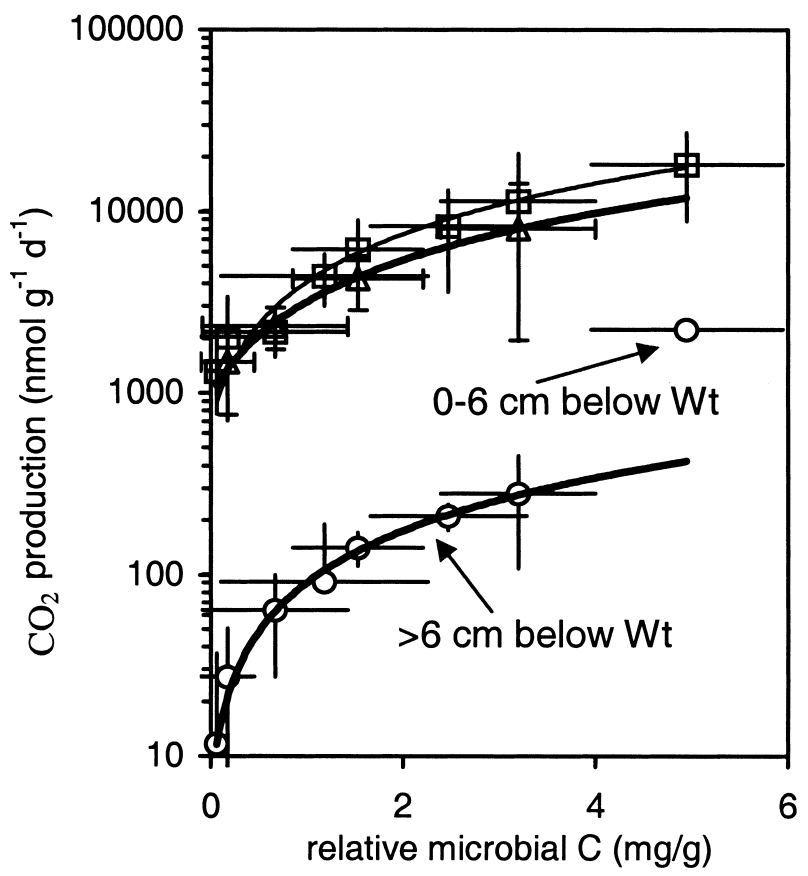

\section{O in situ \\ 口potential aerobic \\ $\Delta$ potential anaerobic}

Figure 6. In situ DIC production rates, potential anaerobic DIC production rates, and potential aerobic production rates vs. relative microbial C. Bars indicate standard deviations.

in the unsaturated peat by a factor of 42 . Potential rates were on average larger than the corresponding diffusive-advective in situ rates by a factor of $2(10 \mathrm{~cm})$ to $26(60 \mathrm{~cm})$. Potential DOC production rates decreased on average from 17000 to $4000 \mathrm{nmol} \mathrm{g}^{-1} \mathrm{~d}^{-1}$ with depth (Figure 4). The water table treatments had no effect on potential DOC production rates.

\section{Microbial biomass}

Microbial C concentrations were largest at the surface (3.7-8.0 $\mathrm{mg} \mathrm{g}^{-1}$, Figure 3A) and decreased with depth. With exception of the surface layer, concentrations were larger in the unsaturated peat of the low water table treatments (Figure 3A). Microbial biomass $\mathrm{C}$ concentrations were correlated to in situ and potential rates of $\mathrm{CO}_{2}$ production (Figure 6). 


\section{Discussion}

As in studies with peat columns devoid of vegetation (Moore and Knowles 1989; Moore and Dalva 1993; Aerts and Ludwig 1997), lowering of the water table level resulted in strong changes of $\mathrm{C}$ fluxes from the mesocosms (Table 1). A water table level decrease by $30 \mathrm{~cm}$ reduced rates of photosynthesis by $24 \%$ (Mer Bleue) and $42 \%$ (ELA). Previously a reduction of $25 \%$ in Sphagnum mass growth with the same water table level decrease was described by Williams et al. (1999). Rates of $\mathrm{CO}_{2}$ production and emissions increased as found by Moore and Dalva (1993) and rates of $\mathrm{CH}_{4}$ production and emission decreased as described by Aerts and Ludwig (1997).

When the water table level was high, $\mathrm{C}$ mineralization rates were small compared to photosynthesis and plant respiration. Plant respiration was estimated by subtracting the mineralization rates, as calculated from the pore water mass balances, from the $\mathrm{CO}_{2}$ exchange rates (Table 1). The relative importance of $\mathrm{C}$ mineralization, however, increased when the water table was lowered. Under these conditions, the average photosynthesis rates decreased from 48 to $27 \mathrm{mmol} \mathrm{m}^{-2}$ $\mathrm{d}^{-1}(\mathrm{n}=8, * \mathrm{P}<0.05$, $\mathrm{t}$-test), whereas the sum of respiration and mineralization increased from 66 to $86 \mathrm{mmol} \mathrm{m}^{-2} \mathrm{~d}^{-1}$, compared to the high water table treatment $(\mathrm{n}=8, * \mathrm{P}<0.05$, $\mathrm{t}$-test). Assuming a jointly response of photosynthesis and plant respiration in response to the change in environmental conditions (Proctor 1982; Chapin and Oechel 1983) and a constant ratio between photosynthesis and plant respiration, plant respiration would have decreased from 66 to $33 \mathrm{mmol} \mathrm{m}^{-2} \mathrm{~d}^{-1}$ and mineralization would have consequently increased from 7.3 to 53 mmol m $\mathrm{m}^{-2} \mathrm{~d}^{-1}$.

When the water table level was low, $\mathrm{C}$ mineralization thus probably became the process with the largest rate in the system. This is qualitatively confirmed by the net $\mathrm{CO}_{2}$ production rates that were calculated using the mass balance approach (Table $1, " \mathrm{CO}_{2}$ net production"). Along with the increase of $\mathrm{C}$ mineralization rates in the unsaturated zone the microbial biomass-C also increased (Figure 3A) suggesting that part of the processed carbon was not mineralized but utilized for microbial biomass synthesis. This was not so in the uppermost layer of the peatland mesocosms, where in both water table treatments $\mathrm{C}$ mineralization proceeded under oxic conditions. In accordance with earlier findings oxic respiration apparently allowed for the build up and maintenance of a larger microbial biomass (McLatchey and Reddy 1998).

The outlined changes in the relative importance of process rates within the $\mathrm{C}$ cycle should be realistic, since a compilation of $\mathrm{CO}_{2}$ and $\mathrm{CH}_{4}$ emission data from column experiments showed that an average water table decrease of $22 \mathrm{~cm}$ resulted in an increase of the median of $\mathrm{CO}_{2}$ fluxes from unvegetated peat columns from 60 to $270 \mathrm{mmol} \mathrm{m}^{-2} \mathrm{~d}^{-1}$ (Figure 7). Such effects are caused by the higher efficiency of aerobic vs. anaerobic $\mathrm{C}$ mineralization. In incubation and column studies aerobic-anaerobic ratios typically range from 1.2 to 6 (Figure 7; Moore and Dalva (1993) and Updegraff et al. (1996), Aerts and Ludwig (1997), Yavitt et al. (1997), Öquist and Sundh (1998)). 

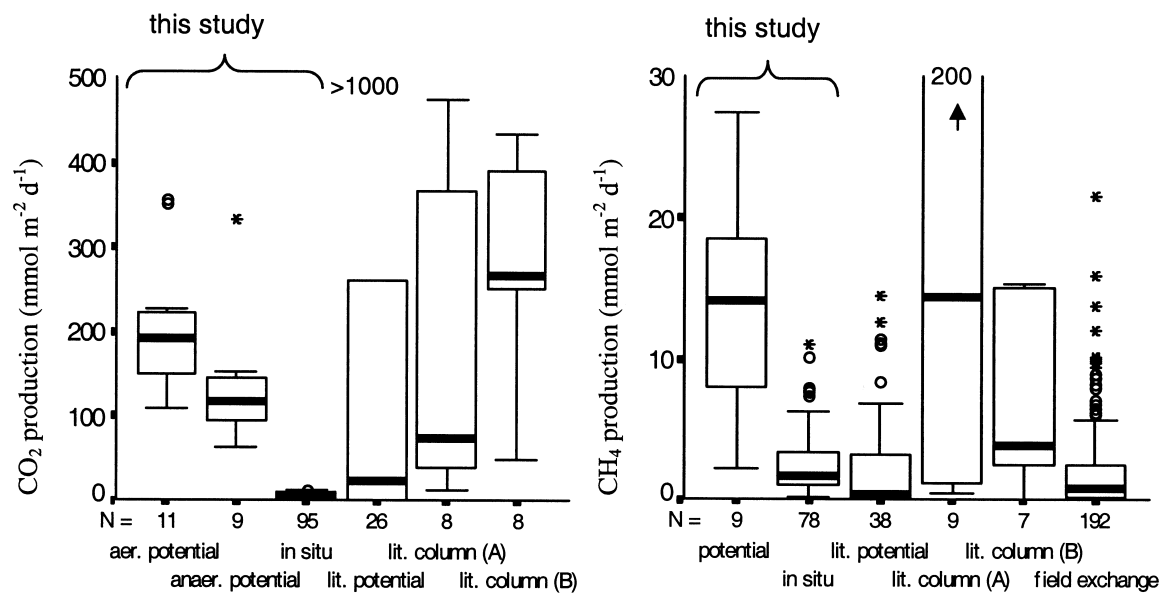

Figure 7. Summary of in situ rates, potential rates, and reported rates of DIC/CO The graph displays median, quartiles, $90 \%$ quantiles, and extreme values. Reported potential rates were recalculated for a $40 \mathrm{~cm}$ profile (bulk density $0.08 \mathrm{~g} \mathrm{~cm}^{-3}$ ), and molar units. "Wt" stands for water table. The "literature" denoted rates were taken from: Aerts \& Ludwig 1997; Aerts \& Toet 1997; Bellisario et al. 1999; Bubier et al. 1993; Bubier 1995; Freeman et al. 1993; Funk et al. 1994; Hall et al. 1996; Liblik et al. 1997; Moore \& Dalva 1993; Moore \& Knowles 1989; Moore et al. 1994; Nykaenen et al. 1998; Schimel 1995; Hogg 1993; Valentine et al. 1994; van den Pol-van Dasselaar \& Oenema 1999; Yavitt et al. 1990; Yavitt et al. 1997

The in situ rates of DOC release obtained in the mesocosms are fairly typical for peatlands although most studies on DOC dynamics in wetlands were carried out on the watershed scale, so that fully comparable in situ and potential DOC production rates are not available. Peatlands have been found to export between 0.2 and $11.5 \mathrm{mmol} \mathrm{m}^{-2} \mathrm{~d}^{-1}$ to discharging streams (Moore 1987, 1988; Urban et al. 1989; Koprivnjak and Moore 1992; Dillon and Molot 1997). DOC release from Thoreau's Bog, an ombrotrophic peatland in the northeastern United States, was 5-10 mmol m $\mathrm{m}^{-2} \mathrm{~d}^{-1}$ (McKnight et al. 1985), which is somewhat lower than the figures obtained in this study (Table 1, "DOC flux dissolved"). In incubations with peats from different depths, Moore and Dalva (2001) reported average release rates of 2.6-3.8 $\mu \mathrm{mol} \mathrm{g}^{-1} \mathrm{~d}^{-1}$ over a 60 day period with a threefold flushing with distilled water. These rates are similar to the rates in the uppermost peat layers in the MB and ELA cores (2.2 to $2.9 \mu \mathrm{mol} \mathrm{g}^{-1} \mathrm{~d}^{-1}$ ) but are much higher than rates at lower depths.

Below the water table DOC release dominated the $\mathrm{C}$ export from peat under the chosen vertical through-flow rate, which represents about twice the average runoff rate at Mer Bleue (ca. $1 \mathrm{~mm} \mathrm{~d}^{-1}$, based on a 8 month unfrozen period; Fraser et al. (2001)). Also, most of the DOC was released by or just below the vegetation layer (Figure 4). This confirms results from incubation experiments showing that the potential DOC release is highest for plant tissues and decreases with an advancing state of decomposition (Moore and Dalva 2001). The water table level had little influence on the in situ and potential DOC production rates (Table 1) and initial 
rates in flask incubations were, particularly at lower depths, one or two orders of magnitude faster than in situ. Previous work has shown that DOC release is strongly correlated with run off from wetlands (Mulholland and Kuenzler 1979; Urban et al. 1989 ) and that contact of peat with water low in DOC releases DOC from the peat matrix (Moore and Dalva 2001). These and our results suggest that the DOC release from peat is constrained by the accumulation of DOC in the pore water.

Methane production and fluxes followed previously reported patterns. Methane consumption, as observed in the unsaturated peat (Figure 5B), has frequently been reported from field and laboratory studies (Klinger et al. 1994; Yavitt et al. 1990) and occurred primarily at the water table (Figure 5B). When the water table was low, methane production was reduced by a factor of 2.5 (ELA) to 3.5 (MB), and the chamber emissions by a factor of 3.6 (ELA) and about 100 (MB). A compilation of available studies shows that in column experiments a difference in water tables of $22 \mathrm{~cm}$ changed the median of $\mathrm{CH}_{4}$ emission rates by factor of 3.8 (Figure 7)

In field studies and in the Mer Bleue mesocosms differences in $\mathrm{CH}_{4}$ emissions with variation in water table levels were much larger than in the ELA mesocosms. On average the logarithm of seasonal $\mathrm{CH}_{4}$ emissions in peatlands changes by $2-5 \%$ per 1-cm difference in average seasonal water table level (Blodau 2002). A plausible explanation for the relatively small effect of the water table change on $\mathrm{CH}_{4}$ emission rates in the ELA mesocosms would be continued ebullition from the saturated into the unsaturated zone, even when the water table was low. According to the difference between fluxes measured with the chamber technique and calculated from concentration profiles (Table 1, diffusive flux vs. chamber flux), the release of bubbles was a primary mechanism of $\mathrm{CH}_{4}$ emissions in the high water table level treatment. When the water table was low at the ELA site dissolved $\mathrm{CH}_{4}$ concentrations also remained in a range $\left(>500 \mu \mathrm{mol} \mathrm{L}^{-1}\right)$ often allowing for ebullition (Chanton et al. 1989; Chanton and Dacey 1991; Shannon and White 1994). In the Mer Bleue mesocosms, showing much smaller rates of $\mathrm{CH}_{4}$ emission, this was not the case (Figure 1D).

Due to the changes in process rates the $\mathrm{C}$ net balance of the mesocosms shifted from a loss of $\mathrm{C}$ of about $21 \mathrm{mmol} \mathrm{m}^{-2} \mathrm{~d}^{-1}$ (Mer Bleue) and $47 \mathrm{mmol} \mathrm{m}^{-2} \mathrm{~d}^{-1}$ (ELA) in the high water table treatment to losses of about $60 \mathrm{mmol} \mathrm{m}^{-2} \mathrm{~d}^{-1}$ (Mer Bleue) and $83 \mathrm{mmol} \mathrm{m}^{-2} \mathrm{~d}^{-1}$ (ELA) in the low water table treatment. According to our estimates the $\mathrm{C}$ mineralization contributed most to this change. Rates of photosynthesis and $\mathrm{CH}_{4}$ production changed less and rates of DOC production did not change (Table 1). It has to be kept in mind though that light intensities in this experiment were low and probably partly responsible for the low rates of photosynthesis and the net loss of carbon from the mesocosms in the high water table treatment.

In addition to the described changes in $\mathrm{C}$ fluxes, an important finding of this study is that changes of the water table level can have in situ effects on $\mathrm{CO}_{2}$ and $\mathrm{CH}_{4}$ production rates that are not controlled by a distinction in aerobic/anaerobic conditions: Lowering of the water table resulted in increased anaerobic in situ rates of $\mathrm{CO}_{2}, \mathrm{CH}_{4}$ and DOC production at larger depths (Figures 3C and 5B). This was 
also indicated by the steep concentration gradients of $\mathrm{CO}_{2}$ and $\mathrm{CH}_{4}$ at low water table level compared to the high water table treatments (Figures $1 \mathrm{C}$ and D). As a result advective fluxes of dissolved $\mathrm{CO}_{2}, \mathrm{CH}_{4}$ and DOC from the mesocosm base decreased only slightly, or not at all, when the water table was lowered (Table 1).

This phenomenon might have been caused by the in situ accumulation of $\mathrm{CO}_{2}$ and $\mathrm{CH}_{4}$ in the deeper peat when the water table was at the surface because large end-product concentrations of biogeochemical processes decrease the available energy from these processes. Under high $\mathrm{CO}_{2}$ and $\mathrm{CH}_{4}$ concentrations the microbial community might thus operate at the thermodynamic limit of metabolism, which is $1 / 4$ to $1 / 3$ of the energy necessary for ATP generation and biomass synthesis (Rothfuss and Conrad 1993; Conrad 1999). For $\mathrm{H}_{2}$-dependent methanogenesis, a Gibbs free energy of $-20 \mathrm{KJ} \mathrm{mol}^{-1}\left(\mathrm{CH}_{4}\right)$ represents the approximate energetic boundary of $\mathrm{CH}_{4}$ production (Conrad 1999). Indirect support for a thermodynamically controlled decrease of $\mathrm{C}$ mineralization rates comes from the observation that in longterm closed anaerobic incubations, rates decrease but can be fully restored by flushing the incubation flask headspace with $\mathrm{N}_{2}$ (Magnusson 1993).

Potential and in situ $\mathrm{CO}_{2}$ production rates significantly correlated with the microbial biomass $C$ (Figure 6), but in situ rates were between 8 to 100 times smaller than the potential aerobic and anaerobic rates obtained in the flask incubations, when $\mathrm{CO}_{2}$ and $\mathrm{CH}_{4}$ concentration levels were still low. This also suggests that the microbial efficiency to process $\mathrm{C}$ was greatly reduced under in situ conditions, either by the accumulation of $\mathrm{CO}_{2}$ and $\mathrm{CH}_{4}$, or by some other reason, which would be related to the physical and chemical disturbance involved in incubating peat. Increased $\mathrm{C}$ mineralization rates may for instance be caused by enhanced substrate release due to redox and enzyme induced chemical breakdown, as well as enhanced recycling of biomass after cell lysis due to aeration of previously anaerobic peat (Freeman, pers. communication, Kieft et al. (1987) and Aller (1994)).

Constraining $\mathrm{C}$ mineralization by accumulation of $\mathrm{CO}_{2}, \mathrm{CH}_{4}$ and DOC in the pore waters would have implications for the long-term development of peatlands and for the $\mathrm{C}$ dynamics under changed hydrologic conditions. Slowing of the decomposition process due to this accumulation would be a inherent result of the build up of deep peat deposits, in which $\mathrm{CO}_{2}$ and $\mathrm{CH}_{4}$ concentrations typically reach levels as high as, or higher than, measured in the mesocosms (Nilsson and Bohlin 1993; Romanowicz et al. 1995; Liblik et al. 1997; Blodau et al. 2002). Vice versa, it can be inferred that decreases in concentrations of decomposition products would accelerate the anaerobic decomposition process. This could, for instance, be caused by water table fluctuations and increased flushing of pore water (Siegel et al. 1995) or by the seasonal removal of $\mathrm{CH}_{4}$ by conduit transport in annual plants containing aerenchyma (Shannon and White 1994; Schimel 1995). 


\section{Acknowledgements}

We thank Dr. Real Roy (Biotechnology Institute Montreal) for the determination of fatty acid concentrations and R. Knowles and J. Yavitt for helpful discussions, M. Romer for the excellent service of the McGill University Phytotron, J. Bubier for the identification of plant species. The work was funded by the Natural Sciences and Engineering Research Council of Canada. C. Blodau was supported by a McGill-McConnell Fellowship, a Government of Canada Award by the International Council for Canadian Studies, and a stipend from the McGill Centre for Global \& Climate Change Research.

\section{References}

Aerts R. and Ludwig F. 1997. Water-table changes and nutritional status affect trace gas emissions from laboratory columns of peatland soils. Soil. Biol. Biochem. 29: 1691-1698.

Aerts R. and Toet S. 1997. Nutritional controls on carbon dioxide and methane emission from Carex dominated peat soils. Soil. Biol. Biochem. 29: 1683-1690.

Aller R.C. 1994. Bioturbation and remineralization of sedimentary organic matter: effects of redox oscillation. Chemical Geology 114: 331-345.

Avery G.B., Shannon R.D., White J.R., Martens C.S. and Alperin M.J. 1999. Effect of seasonal changes in the pathways of methanogenesis on the $\delta^{13} \mathrm{C}$ values of pore water methane in a Michigan peatland. Global Biogeochem. Cycles 13: 475-484.

Bayley S.E., Behr R.S. and Kelly C.A. 1986. Retention and Release of S from a freshwater wetland. Water Air Soil Pollut. 31: 101-114.

Bellisario L.M., Bubier J.L., Moore T.R. and Chanton J.B. 1999. Controls on $\mathrm{CH}_{4}$ emissions from a northern peatland. Global Biogeochem. Cycles 13: 81-91.

Blodau C. 2001. Carbon Biogeochemistry in Northern Peatlands: Regulation by Environmental and Biogeochemical Factors. PhD Thesis, McGill University, Montreal, 189 p.

Blodau C. 2002. Carbon cycling in peatlands - A review of processes and controls. Env. Rev. 10: 111134.

Blodau C. and Moore T.R. 2002a. Macroporosity affects water movement and pore water sampling in peat soils. Soil Sci. 167: 98-109.

Blodau C., Roehm C.L. and Moore T.R. 2002. Iron, sulphur, and dissolved carbon dynamics in a northern peatland. Arch. Hydrobiol. 154: 561-583.

Blodau C. and Moore T.R. 2002b. Experimental response of peatland carbon dynamics to a water table fluctuation. Aqua. Sci. (in press).

Brookes P.C., Landman A., Pruden G. and Jenkinson D.S. 1985. Chloroform fumigation and the release of soil nitrogen: a rapid direct extraction method to measure microbial biomass nitrogen in soil. Soil Biol. Biochem. 17: 837-842.

Bubier J.L. 1995. The relationship of vegetation to methane emission and hydrochemical gradients in northern peatlands. J. Ecology 83: 403-420.

Bubier J.L., Moore T.R. and Roulet N.T. 1993. Methane emissions from wetlands in the midboreal region of northern Ontario, Canada. Ecology 74: 2240-2254.

Chanton J.P., Martens C.S. and Kelley C.A. 1989. Gas transport from methane-saturated, tidal freshwater and wetland sediments. Limnol. Oceanogr. 34: 807-819.

Chanton J.P. and Dacey J.W.H. 1991. Effects of vegetation on methane flux, reservoirs, and carbon isotopic composition. In: Sharkey T.D., Holland E.A. and Mooney H.A. (eds), Trace Gas Emissions by Plants. Academic Press, SanDiego, pp. 65-92. 
Chapin F.S. III and Oechel W.C. 1983. Photosynthesis, respiration, and phosphate absorption by carex aquatilis ecotypes along latitudinal and local environmental gradients. Ecology 64: 743-751.

Clymo R.S. 1984. The limits to peat bog growth. Phil. Trans. R. Soc. London B 303: 605-654.

Clymo R.S. 1970. The growth of Sphagnum. Methods of measurement. J. Ecology 58: 13-49.

Conrad R. 1999. Contribution of hydrogen to methane production and control of hydrogen concentrations in methanogenic soils and sediments. FEMS Microbiol. Ecol. 28: 193-202.

Cornel P.K., Summers R.S. and Roberts P.V. 1985. Diffusion of humic acid in dilute aqueous solution. J. Colloid. Interface Sci. 110: 149-164.

Dillon P.J. and Molot L.A. 1997. Effect of landscape form on export of dissolved organic carbon, iron, and phosphorus from forested stream catchments. Wat. Res. Res. 33: 2591-2600.

Fraser C.J.D., Roulet N.T. and Moore T.R. 2001. Hydrology and dissolved organic carbon biogeochemistry in an ombrotrophic bog. Hydrol. Process 15: 3151-3166.

Freeman C., Lock M.A. and Reynolds B. 1993. Fluxes of $\mathrm{CO}_{2}, \mathrm{CH}_{4}$ and $\mathrm{N}_{2} \mathrm{O}$ from a Welsh peatland following simulation of water table draw-down: potential feedback to climate change. Biogeochemistry 19: 51-60.

Fechner-Levy E.J. and Hemond H.F. 1996. Trapped methane volume and potential effects on methane ebullition in a northern peatland. Limnol. Oceanogr. 41: 1375-1383.

Fung I., John J., Lerner J., Mathews M., Prather M., Steele L. et al. 1991. Global budgets of atmospheric methane: results from a three-dimensional global model synthesis. J. Geophys. Res. 6: 13033-13065.

Funk D.W., Pullman E.R., Peterson K.M., Crill P.M. and Billings W.D. 1994. Influence of water table on carbon dioxide, carbon monoxide and methane fluxes from taiga bog microcosms. Global Biogeochem. Cycles 8: 271-278.

Hall G.H., Simon B.M. and Pickup R.W. 1996. $\mathrm{CH}_{4}$ production in blanket bog peat: A procedure for sampling, sectioning, and incubating samples whilst maintaining anaerobic conditions. Soil Biol. Biochem. 28: 9-15.

Hogg H.E. 1993. Decay potential of hummock and hollow Sphagnum peats at different depths in a Swedish raised mire. Oikos 66: 269-278.

Hornibrook E.R.C., Longstaff F.J. and Frye W.S. 1997. Spatial distribution of microbial methane production pathways in temperate zone wetland soils: Stable carbon and hydrogen isotope evidence. Geochim. Cosmochim. Acta 61: 745-753.

Jin Y. and Jury W.A. 1996. Characterizing the dependence of gas diffusion coefficient on soil properties. Soil Sci. Soc. Am. J. 60: 66-71.

Kettunen A., Kaitala V., Lehtinen A., Lohila A., Alm J., Silvola J. et al. 1999. Methane production and oxidation potentials in relation to water table fluctuations in two boreal mires. Soil Biol. Biochem. 31: 1741-1749.

Kieft T.L., Soroker E. and Firestone M.K. 1987. Microbial biomass response to a rapid increase in water potential when dry soil is wetted. Soil Biol. Biochem. 19: 119-126.

Kivinen E. and Pakarinen P. 1981. Geographical distribution of peat resources and major peatland complex types in the world. Ann. Acad. Sci. Fenn. Ser. A., 32, No. 132: 1-28.

Klinger L.F., Zimmermann P.R., Greenberg J.P., Heidt L.E. and Guenther A.B. 1994. Carbon trace gas fluxes along a successional gradient in the Hudson Bay lowland. J. Geophys. Res. 99: 1469-1494.

Koprivnjak J.F. and Moore T.R. 1992. Sources, sinks and fluxes of dissolved organic carbon in subarctic fen catchments. Arct. Alp. Res. 24: 204-210.

Lerman A. 1979. Geochemical Processes. John Wiley \& Sons, New York.

Liblik L.K., Moore T.R., Bubier J.L. and Robinson S.D. 1997. Methane emissions from wetlands in the zone of discontinuous permafrost: Fort Simpson, North West Territories, Canada. Global Biogeochem. Cycles 11: 485-494.

Magnusson T. 1993. Carbon dioxide and methane formation in forest mineral and peat soils during aerobic and anaerobic incubations. Soil Biol. Biochem. 25: 877-883.

McKnight D., Thurman E.M. and Wershaw R.L. 1985. Biogeochemistry of aquatic humic substances in Thorau's bog, Concord, Massachusetts. Ecology 66: 1339-1352. 
McLatchey G.P. and Reddy K.R. 1998. Regulation of organic matter decomposition and nutrient release in a wetland soil. J. Env. Qual. 27: 1268-1274.

Millington R.J. and Quirk J.P. 1961. Permeability of porous solids. Trans. Faraday Soc. 57: 1200-1207.

Moore T.R. and Dalva M. 1993. The influence of temperature and water table on carbon dioxide and methane emissions from laboratory columns of peatland soils. J. Soil Sci. 44: 651-664.

Moore T.R. and Dalva 2001. Some controls on the release of dissolved organic carbon by plant tissues and soils. Soil Sci. 166: 38-47.

Moore T.R. and Knowles R. 1989. The influence of water table levels on methane and carbon dioxide emissions from peatland soils. Can. J. Soil. Sci. 69: 33-38.

Moore T.R. 1987. Patterns of dissolved organic matter in subarctic peatlands. Earth Surf. Proc. Landf. 12: 387-397.

Moore T.R. 1988. Dissolved iron and organic matter in northern peatlands. Soil Sci. 145: 70-76.

Moore T.R., Heyes A. and Roulet N.T. 1994. Methane emissions from wetlands, southern Hudson Bay lowland. J. Geophys. Res. 99: 1455-1467.

Mulholland P.J. and Kuenzler E.J. 1979. Organic carbon export from upland and forested wetland watersheds. Limnol. Oceanogr. 24: 960-966.

Nilsson M. and Bohlin E. 1993. Methane and carbon dioxide concentrations in bogs and fens - with special reference to the effects of the botanical composition of the peat. J. Ecol. 81: 615-625.

Nykaenen H., Alm J., Silvola J. and Tolonen K. 1998. Methane fluxes on boreal peatlands of different fertility and the effect of long-term experimental lowering of the water table on flux rates. Global Biogeochem. Cycles 12: 53-69.

Öquist M. and Sundh I. 1998. Effects of a transient oxic period on mineralization of organic matter to $\mathrm{CH}_{4}$ and $\mathrm{CO}_{2}$ in anoxic peat incubations. Geomicrobiology 15: 325-333.

Proctor M.C.F. 1982. Physiological ecology: water relations, light and temperature responses, carbon balance. In: Smith A.J.E. (ed.), Bryophyte Ecology. Chapman and Hall, London, pp. 333-382.

Romanowicz E.A., Siegel D.I., Chanton J.P. and Glaser P.H. 1995. Temporal variations in dissolved methane deep in the Lake Agassiz peatlands, Minnesota. Global Biogeochem. Cycles 9: 197-212.

Rothfuss F. and Conrad R. 1993. Thermodynamics of methanogenic intermediary metbolism in littoral sediment of Lake Constance. FEMS Microbiol. Ecol. 12: 265-276, 717-733.

Shannon R.D. and White J.R. 1994. A three year study of controls on methane emissions from two Michigan peatlands. Biogeochemistry 27: 35-60.

Schimel J.P. 1995. Plant transport and methane production as controls on methane flux from arctic wet meadow tundra. Biogeochemistry 28: 183-200.

Siegel D.I., Reeve A.S., Glaser P.H. and Romanowicz E.A. 1995. Climate driven flushing of pore water in peatlands. Nature 374: 531-533.

Sparling G.P., Feltham C.W., Reynolds J., West A.W. and Singleton P. 1990. Estimation of soil microbial $\mathrm{C}$ by a fumigation-extraction method: use on soils of high organic matter content and a reassessment of the $\mathrm{k}_{\mathrm{EC}}$-factor. Soil Biol. Biochem. 22: 301-307.

Updegraff K., Pastor J., Bridgham S.D. and Johnston C.A. 1996. Environmental and substrate controls over carbon and nitrogen mineralization in northern wetlands. Ecol. Appl. 5: 151-163.

Urban N.R., Bayley S.E. and Eisenreich S.J. 1989. Export of dissolved organic carbon and acidity from peatlands. Wat. Res. Res. 25: 1619-1628.

Valentine D.W., Holland E.A. and Schimel D.S. 1994. Ecosystem and physiological controls over methane production in northern wetlands. J. Geophys. Res. 99: 1565-1571.

Van den Pol-van Dasselaar A. and Oenema O. 1999. Methane production and carbon mineralisation of size and density fractions of peat soils. Soil Biol. Biochem. 31: 877-886.

Voroney R.P., Winter J.P. and Beyaert R.P. 1993. Soil microbial biomass C and N. In: Carter M.R. (ed.), Soil Sampling and Methods of Analysis. Lewis Publishers, Boca Raton, USA.

Walter B. and Heimann M. 2000. A process based climate sensitive model to derive methane emissions from natural wetlands: Application to five wetland sites, sensitivity to model parameters, and climate. Global Biogeochem. Cycles 14: 745-765.

Whiting G.J. and Chanton J.P. 1993. Primary production control of methane emissions from wetlands. Nature 364: 794-795. 
Williams B.L., Buttler A., Grosvernier P., Francez A.J., Gilbert D., Ilomets M. et al. 1999. The fate of $\mathrm{NH}_{4} \mathrm{NO}_{3}$ added to Sphagnum magellanicum carpets at five European mire sites. Biogeochemistry 45: 73-93.

Yavitt J.B., Downey D.M., Lancaster E. and Lang G.E. 1990. Methane consumption in decomposing Spaghnum derived peat. Soil Biol. Biochem. 22: 441-447.

Yavitt J.B., Lang G.E. and Wieder R.K. 1987. Control of carbon mineralization to $\mathrm{CH}_{4}$ and $\mathrm{CO}_{2}$ in anaerobic, Sphagnum derived peat from Big run Bog, West Virginia. Biogeochemistry 4: 141-157.

Yavitt J.B., Williams C.J. and Wieder R.K. 1997. Production of methane and carbon dioxide in peatland ecosystems across North America: Effects of temperature, aeration, and organic chemistry of the peat. Geomicrobiol. J. 14: 299-316. 